\title{
THE IMPACT OF THE EUROPEAN COURT OF JUSTICE CASE-LAW ON INDIRECT TAXES SYSTEM IN POLAND - SELECTED PROBLEMS
}

Directives and their implementation into our legal system as well as case-law of the European Court of Justice (ECJ) play a crucial role in the establishment and implementation of tax law in Poland. Those acts and judgments gained the significant meaning with the accession of Poland to the European Union. Unfortunately, new Polish tax acts, allegedly harmonized to Community regulations, after over four years of being in force, are still brought into question by the ECJ and the Polish legislator repeatedly delays or even ignores the rulings of the ECJ in the process of tax law establishment. In my opinion, even more objections should be raised against the actions of tax authorities (especially of the first of instance) in the scope of implementation of the Court judgments as these institutions most frequently ignore the judgments while making decisions pointing out the necessity of the application of domestic regulations. However, in compliance with Article 2 Part I of the Treaty ${ }^{1}$ from the date of accession new member states shall be bound by the provisions of the establishing Treaties and the acts adopted by the Community institutions and European Central Bank before the day of the accession. Moreover, the fact that Community law is a part of Polish legal system is also proved by the provisions of Article 87 and Article 91 (3) of the Constitution of the Republic of Poland. These provisions introduce the structure of sources of law and application priority of international agreements and legislation of the international organizations with reference to domestic acts, as long as these acts cannot be co-applied. ${ }^{2}$

Additionally, as the regional administrative court stated in one of its rulings, the interpretation of the Community law contained in ECJ case-law is binding not only for courts giving decisions, but also for other member state institutions, which is concluded in Article 234 of the Treaty ${ }^{3}$.

\footnotetext{
Treaty on the Accession of the Republic of Poland to the European Union (OJ L 236, 23 September 2003) See more in this scope wyrok WSA w Warszawie $z$ dnia 25 maja 2007 r., sygn. akt III SA/Wa 240/07, LEX nr 309079.

See wyrok WSA z dnia 12 marca 2008 r., sygn. akt I SA/OI 31/2008, nie publikowany.
} 
The Impact of the European Court of Justice Case-Law on Indirect Taxes System...

Fortunately, the lack of the implementation of the Court judgments is not a rule, however, it constitutes an exception frequently made. Some crucial examples (in the author's opinion) of the partial or absolute lack of the implementation of the ECJ rulings in the scope of provisions establishment on indirect taxes in Poland will be presented.

The impact of the judgments on application of that law will be taken into consideration as well. Due to the essence of the issue and an extremely large extent of the Court case-law the article is confined to the examples only on value added tax and excise tax in Poland.

One of the most crucial interpretative problems on value added tax (especially at the eastern border of Poland), which was heard before the Court, was a possibility given to a taxable persons to apply a reduced rate $0 \%$ of VAT as a so-called VAT refund for travellers (Tax Free for Tourists). Pursuant to Article 126 (1) of the Act on $\mathrm{VAT}^{4}$, natural persons who are not residents within the territory of the Community, shall be entitled to VAT refund paid on acquisition of goods within the territory of the country, which have been exported from the Community in an untouched state in the personal luggage of travellers. However, there are several conditions which have to be met to obtain the reimbursement, contained in other provisions of the Act. First of all, the acquisition of goods should take place by the registered taxable person who keeps records with a cash register and has drawn up the agreements on VAT refund for travellers. Moreover, the vendors must notify the head of tax authority that they are vendors, provide travellers with written information on VAT refund regulations in four languages, mark the retail outlets with a sign informing on the possibility to purchase good in these outlets and also inform the head of tax authority on the place where travellers can obtain a refund. ${ }^{5}$ It is not the refund of the tax that is crucial to VAT reimbursement for travelers but the possibility to apply the reduced rate $0 \%$ of VAT by a taxable person on the supply of goods from which the tax refund has been made. Many conditions must be fulfilled to apply the rate $0 \%$ by a taxable person and as it seems they do not always depend on the taxable person's will and knowledge. Under Article 128 of the Act on VAT the presentation of the personal document (which includes the amount of tax paid at the moment of sale of goods) which was issued by vendor to the traveller constitutes the grounds for the tax refund. Goods exportation should be confirmed on this document with the border customs office's stamp. Customs office confirms the exportation after the exported goods have been presented by the traveller and the data included in the passport or other identity document have been checked. Moreover, in order to apply $0 \%$ tax rate the taxable person has to have the exportation document confirmed before the VAT return form

$4 \quad$ Ustawa z dnia 11 marca 2004 r. o podatku od towarów i usług, Dz. U. Nr 54, poz. 535 ze zm.

$5 \quad$ Article 127 of the VAT Act. 
is submitted for a particular month. A legal question arose in the scope of these provisions and concerned both the exportation of goods outside the Community and stamps and signatures on TAX FREE document. The issue also resulted in doctrine disputes and differences in jurisdiction on the grounds of the 'old' Act on Value Added Tax and Excise Tax ${ }^{6}$. Tax authorities questioned the possibility of the $0 \%$ VAT rate application whenever one of these elements was defective (lack of signature, lack of stamp, a stamp was not genuine etc.). However, the regional administrative courts' standpoint was that a taxable person cannot be liable for the third parties' actions that were not familiar to him/her or which s/he could not have learned of despite his/her due diligence. The Regional Administrative Court's judgment of 11 December $2007^{7}$ could be an example here, which states that even a lack of customs office border stamp does not prove that the goods have not been exported and as a consequence the taxable person may not be deprived of the right to apply the $0 \%$ VAT reduced rate only on that ground ${ }^{8}$ The legitimacy of this case-law line, created thanks to the Regional Administrative Court case-law in Bialystok, was confirmed by the ECJ in 2008. The Court's judgment of 21 February 2008, case C-271/06 Netto Supermarket GmbH \& OHG versus Finanzamt Malchin affirmed that Article 15(2) of Sixth Directive 77/388 must be interpreted as not precluding a member state from granting an exemption from value added tax on the supply of exported goods to a destination outside the European Community, when the premises for such an exemption are not met but the taxable person could not be aware (despite his/her due commercial diligence) that they were not met, due to the fact that the purchaser provided a forged export document.

The Court noticed that it would be contrary to the principle of legal certainty if a member state which has laid down the conditions for the application of the exemption of supplies of goods for export to a destination outside the Community (by prescribing, among other things, a list of the documents to be presented to the competent authorities and which accepted, initially, the documents presented by the supplier as evidence establishing entitlement to the exemption) could subsequently oblige the supplier to account for the value added tax on that supply, where it transpires that, due to the purchaser's fraud, of which the supplier had and could have had no knowledge, the conditions for the exemption were in fact not met. ${ }^{9}$ Following the ECJ judgment administrative courts continued this line of case-law and started applying the Court's judgment during proceedings directly. A special attention must

\footnotetext{
6 See Article 21a-21e ustawy z dnia 8 stycznia 1993 r. o podatku od towarów i usług oraz o podatku akcyzowym, Dz. U. Nr 11, poz. 50 ze zm.

7 I SA/Bk 487/07, nie publikowany

8 See also wyrok WSA z dnia 12 grudnia 2006 r., I SA/Bk 312/06, nie publikowany; wyrok WSA z dnia 21 marca 2006 r., I SA/Bk 10/06, nie publikowany; wyrok WSA z dnia 29 czerwca 2005 r., I SA/Bk 128/05, nie publikowany; wyrok WSA z dnia 25 stycznia 2006 r., I SA/Bk 377/05, nie publikowany. See more A. Bącal (red.), Orzecznictwo ETS a polska ustawa o VAT, Wrocław 2008, s. 575 i n.
} 
be paid to 9 July 2008 judgment of the Regional Administrative Court ${ }^{10}$, in which the Court affirmed that "taking into consideration Article 15(2) of Sixth Directive, the interpretation of this provision made by the ECJ in case C-271/06 of 21 February of 2008 and principles of Community law, without proving that the taxable person knew or even by exercising due commercial care could have known and should have become aware that there is no stamp mark of customs office on the issued TAX FREE document or the goods, mentioned in this document, have not been exported abroad in fact, $\mathrm{s} /$ he may not be deprived of the application for the reduced rate $0 \%$ of tax". Unfortunately, despite clear and reasonable indications from case-law courts and doctrine, the Polish legislator did not decide to make any changes in this matter when broad amendments of VAT Act were being prepared. No crucial changes in this scope [except the provision of Article 129 para.1 (2) in which the expression "before submitting the tax return form" was turned into "within the expiry date for submitting the tax return form" ${ }^{11}$ were introduced in 7 September 2008 Act on the amendment of VAT Act and other acts.

Another crucial ruling of the ECJ to Polish VAT Act is the ruling which refers to the possibility of obtaining a refund of excess input tax over the due one within 60 rather than 180 days by taxable persons who have begun their business activity or keep it for period less than 12 months. According to Article 97 (5) of the Act on VAT the time limit of the refund of excess input tax over the due one shall be extended up to 180 days in the case of taxable persons who commence a taxable activity or taxable persons who have commenced taxable activities within the period of less than 12 months before the application for the registration for intra-Community transactions is submitted. It does not, however, apply to entities who left a deposit in the amount of 250,000 zlotys in the tax authorities. Nevertheless, the ECJ recognized those provisions to be contrary to European law. The Court stated in its judgment of 10 July of $2008^{12}$ that "Article 18(4) of the Sixth Council Directive 77/388/EEC of 17 May 1977 on the harmonisation of the laws of the Member States relating to turnover taxes (Common system of value added tax: uniform basis of assessment, as amended by Council Directive 2005/92/EC of 2 December 2005) as well as the principle of proportionality oppose the national regulations on VAT which extend the time limit for the tax refund for new taxable persons from 60 to 180 days unless they leave a deposit to a value of PLN 250000.

Such provisions cannot be considered as "special measures for derogation" intended to prevent certain types of tax evasion or avoidance within the meaning of Article 27(1) of the Sixth Directive 77/388." The amendment of the Act on VAT

I SA/Bk 162/08, nie publikowany

See Article 1 (62) of the amending act

Case C-25/07, Alicja Sosnowska versus Dyrektor Izby Skarbowej we Wrocławiu Ośrodek Zamiejscowy w Wałbrzychu 
mentioned above, which will come into force on 1 January 2009, seems to bring in a positive aspect as Art.97 items (5) to (7) has been deleted by the legislator and the basic time of 60 days for the refund with the possibility of its shortening to 25 days has been accepted. The legislator, however, maintained the time limit of 180 days (although it is not consistent with the Court ruling) as the basic time limit for the taxable persons who have not carried out activities being subject to tax in tax period. This time limit may be shortened to 60 days at the taxpayer's request, on condition of the security on his/her property. ${ }^{13}$

With reference to excise taxation, a special attention must be paid to judgments concerning excise tax assessment on second-hand vehicles imported and sold before their first registration. Under the Excise Tax, a ceiling rate was determined at $65 \%$ of the tax base pursuant to Article 75 (1) of the Act on Excise Tax. ${ }^{14}$ It should be added that the rate has remained unchanged till today, but of course in connection with the rulings of the ECJ, it does not apply to passenger vehicles older than two years, acquired in other member states. The problem of application of this rate on the purchase of other harmonized goods, however, still exists. Under Article 90 of the Treaty no member state shall impose, directly or indirectly, on the products of other member states any internal taxation of any kind in excess of that imposed directly or indirectly on similar domestic products. Furthermore, this provision prohibits the imposition of (direct or indirect) internal taxes to protect products of the member state. The judgment of the ECJ of 18 September 2007 case C-313/05 was crucial in the scope of the imposition of excise tax on passenger vehicles older than two years. The Court in its ruling stated that the first paragraph of Article 90 of the Treaty is to be interpreted as opposing an excise duty with reference to the amount of the duty imposed on second-hand vehicles over two years old, acquired in a member state other than that which introduced such a duty exceeds the residual amount of the same duty incorporated into the purchase price of similar vehicles which had been previously registered in the member state which introduced that duty. It is for the national court to examine whether the legislation at issue in the main proceedings, in particular the application of Article 7 of the Ordinance of the Minister for Finance of 22 April 2004 on Lowering of the Rates of Excise Duty, has such an effect. This means that, in principle, a Polish act cannot impose higher taxes than those in the given country, because it could infringe the principle of the neutrality of taxes and constitute a specific duty on imports..$^{15}$ The thesis of that decision was confirmed in another the ECJ judgment of 17 July 2008, case C-426/07 Dariusz Krawczyński versus Dyrektor Izby Celnej w Białymstoku. ${ }^{16}$ The rulings of the ECJ are also

See VAT w praktyce, pozycja wymienno kartkowa Warszawa 2008, aktualizacja listopad 2008, s. 8 i n. Ustawa z dnia 23 stycznia 2004 r. o podatku akcyzowym, Dz. U. Nr 29, poz. 257 ze zm.

See K. Lasiński-Sulecki, glosa do wyroku TS z dnia 18 stycznia 2007 r., C-313/05, PP 2007, nr 4, s. 41 LEX nr 399225 
The Impact of the European Court of Justice Case-Law on Indirect Taxes System...

reflected in case-law of regional administrative courts in Poland. For example, in the judgment of 25 May 2007 r. the Regional Administrative Court in Warsaw ${ }^{17}$ affirmed that "with regard to guarantee function of Article 90 of the Treaty of Rome of 1957 establishing the European Community, under which it is unacceptable to impose higher taxes than those imposed on similar domestic products and methods of determining the excise tax on secondhand vehicles, which has come into force in the country and whose starting point is the declared price of the vehicle, the basis for calculating the excise tax payable should be the vehicle transaction price. The only upper limit of the tax should be the amount of excise tax included in the market value of similar vehicles, which were previously registered in Poland i.e. the residual excise tax". The similar position was taken by the Regional Administrative Courts in Poznan and Bialystok. ${ }^{18}$ The consequence of settled line of case-law was the Act on Overpayment Refund of Excise Tax Paid for the Acquisition of Intra-Community Transactions or Import of a Passenger Vehicle. ${ }^{19}$ However, it might be worrying that the act came into force after one and a half year from the first rulings of the Court, which means slow process of implementation of EU directives into the Polish tax system. This phenomenon should be evaluated as clearly negative. The fact, that the act concerns only the period from 1 May 2004 to 30 November 2006 and taxable persons of excise duty exclusively, must be emphasized. This, however, results in confusion in the scope of obtaining the excess refund by the taxable person who got rid of passenger vehicle, purchased within intra-Community transaction, before its first registration. The question of intra- Community acquisitions of passenger vehicles as well as import of those vehicles have been solved in a completely different way, probably due to the referred judgments, in the draft of new Act on Excise Tax. Chapter V of the draft, which entirely concerns the passenger vehicles acquisition (Art. 96 to Art. 108 of the draft) ${ }^{20}$, includes very detailed regulations in this scope.

Summing up the above considerations, it can be concluded that the influence of the ECJ's rulings on tax law application in scope of indirect taxes in Poland is an extremely important and these rulings are fully used by the administrative judiciary. The application of the Court experience on the stage of first instance, in which caselaw are used, are much worse. The discrepancies between Polish acts and Community provisions on the stage of tax law establishment are also slowly but systematically eliminated. Although some objections may be raised with the reference to the pace of the proceedings, the process should be regarded as undoubtedly positive.

17 sygn. akt III SA/Wa 240/07, LEX nr 309079

18 See wyrok WSA w Poznaniu z dnia 16 marca 2007 r., sygn. akt I SA/Po 518/07, „Monitor Podatkowy” 2008, nr 2 , s. 23 oraz wyrok WSA w Białymstoku z dnia 30 lipca 2008 r., sygn. akt I SA/Bk 206/08, nie publikowany.

19 Ustawa z dnia 9 maja 2008 r. o zwrocie nadpłaty w podatku akcyzowym zapłaconym z tytułu nabycia wewnątrzwspólnotowego albo importu samochodu osobowego, Dz. U. Nr 118, poz. 745

20

See the Bill on Excise Tax of 6 October 2008 (druk sejmowy nr 1083) 


\section{Streszczenie}

Wpływ orzecznictwa Europejskiego Trybunału Sprawiedliwości na stosowanie prawa podatkowego w zakresie podatków pośrednich w Polsce jest niezmiernie istotny i orzecznictwo to jest wykorzystywane w pełni przez sądownictwo administracyjne. Znacznie gorzej jest z korzystaniem z doświadczeń Trybunału na płaszczyźnie pierwszoinstancyjnej przez organy podatkowe, chociaż już zauważa się takie decyzje, w których to orzecznictwo jest wykorzystywane. Powoli, lecz systematycznie, likwidowane są także niezgodności polskich ustaw z przepisami wspólnotowymi na etapie tworzenia prawa podatkowego. Chociaż można mieć zastrzeżenia do tempa tego postępowania, sam proces należy uznać za jednoznacznie pozytywny. 